\title{
PENGARUH PENYULUHAN MAKANAN BERGIZI DENGAN METODE ULAR TANGGA TERHADAP PENINGKATAN PENGETAHUAN ANAK-ANAK
}

\author{
Nurul Hidayah $^{1}$, M. Thonthowi Jauhari ${ }^{1}$ dan M. Zulfikar Al fariki ${ }^{1}$ \\ ${ }^{1}$ Jurusan Gizi, Universitas Bumigora Mataram, Indonesia \\ Jl. Ismail Marzuki No 22 Mataram Telp./Fax. (0370) 633837 \\ nurulhidayah@universitasbumigora.a.c.id
}

\begin{tabular}{l}
\hline Article Info \\
\hline Article history: \\
Received January $14^{\text {th }}, 2021$ \\
Revised February $21^{\text {th }}, 2021$ \\
Accepte March $25^{\text {th }}, 2021$
\end{tabular}

\section{Kata Kunci :}

Anak-anak; Makanan Bergizi; permainan Ular Tangga; Post-tes; Sosialisasi

\begin{abstract}
Background : Health issues in Indonesia are still on the top topic. One of them is malnutrition and obesity which cause Indonesia encounters "double burden of malnutrition". Sharing knowledge to children is a good starting point to fix the issue. This can increase children's knowledge and brings Indonesia to escalate the quality of human resources in the future.
\end{abstract}

Objective : The purpose of this research is to know the effectivity of socialization hold by ladder game method to the elevation of children's knowledge into nutritious foods.

Method : This has been done by three main steps; pre-test session, intervention, and post-test session. During pre-test and post-test, students were given several questions then the answers were analyzed using SPSS.

Results : The results were analyzed statistically to highlight the description results which depicted that there is an influence of ladder game method during socialization to the increase of children's knowledge. After giving a post-test, it showed a better result compared to pre-test. During pretest mean was 11.9 while at the post-test it reached approximately 15.

Conclusion : It can be said that after the intervention by the ladder game method, the children's insight is much more increasing even though it had no significancy

\begin{abstract}
ABSTRAK
Latar Belakang : Masalah kesehatan di Indonesia masih menjadi topik hangat. Salah satunya adalah masalah malnutrisi dan juga obesitas yang menjadikan Indonesia menghadapi beban ganda dari malnutrisi (double burden of malnutrition). Berbagi pengetahuan kepada anak-anak sejak dini merupakan salah satu cara untuk menghadapi isu ini. Hal tersebut dapat meningkatkan pengetahuan anak sehingga Indonesia mampu memperbaiki sumber daya manusia ke depannya.
\end{abstract}

Tujuan : Tujuan penelitian ini adalah untuk mengetahui efektifitas sosialisasi dengan menggunakan metode permainan ular tangga terhadap peningkatan pengetahuan anak-anak terhadap makanan bergizi

Metode : Kegiatan ini dilakukan dalam tiga sesi; sesi pre-tes, intervensi, dan sesi pos-tes. Pre-tes dan pos-tes dilakukan dengan memberikan beberapa pertanyaan kemudian jawaban tersebut dianalisa menggunakan SPSS. 
Hasil : Hasil penelitian yang telah dianalisa secara statistic menunjukkan pengaruh antara penggunaan metode ular tangga selama sosialsisasi terhadap peningkatan pengetahuan anak-anak. Setelah dilakukan pos-tes, hasil tes anak-anak menunjukkan peningkatan. Nilai mean ketika pre-tes yaitu 11,9 sedangkan ketika pos-tes sekitar 15.

Kesimpulan : Intervensi dengan menggunakan metode ular tangga mampu meningkatkan pengetahuan anak-anak terhadap makanan bergizi; meskipun tidak secara signifikan.

\section{PENDAHULUAN}

Makanan bergizi merupakan makanan yang jika dikonsumsi memberikan pengaruh positif bagi tubuh. Anakanak membutuhkan makanan bergizi untuk proses pertumbuhan dan daya kembang mereka. Berbekal ilmu pengetahuan yang cukup, anak-anak lambat laun akan sadar akan pentingnya mengkonsumsi makanan bernutrisi ditambah lagi melalui dukungan orang tua dan lingkungan sekitar.

Perbaikan pola makan anak dapat diarahkan sesuai dengan aturan makanan bergizi seimbang. Salah satu rekomendasi makanan bergizi seimbang yaitu melalui konsumsi buah dan sayur (KEMENKES, 2014). Buah dan sayur mengandung nutrisi yang baik jika dikonsumsi anak sehingga penting untuk disosialisasikan.

Permasalahan gizi di Indonesia umumnya memang masih tampak signifikan meskipun keadaan ekonomi telah membaik. Kekurangan gizi ini masih sangat tinggi bahkan hingga menghadapi "double burden of malnutrition" diakibatkan timbulnya masalah lain seperti kegemukan atau obesitas (BAPPENAS, 2019). Menurut analisa BAPPENAS, penyebab beban ganda masalah gizi yaitu tiga hal, pertama akibat kurang memadainya konsumsi pangan serta kerawanan pangan; kedua akses pelayanan Kesehatan yang tidak memadai; ketiga berkaitan dengan praktik PMBA.

Anak yang masih berada dalam masa sekolah tentunya membutuhkan asupan nutrisi setiap harinya sebagai sumber energy, mengganti sel yang rusak, pertumbuhan dan juga menjaga Kesehatan. Oleh karena itu, pada dasarnya yang dibutuhkan adalah karbohidrat, protein, lemak, vitamin, mineral dan air terutama bagi anak usia 10-12 tahun (BPOM RI, 2013). Berkaitan dengan hal ini, tidak semua anak mengerti dan paham dalam mengatur serta memilih makanan bergizi untuk pemenuhan kebutuhan sehari-hari. Meski diberikan pengetahuan di sekolah, anak-anak tetap harus diberikan pengarahan akan hal ini terutama di masa pandemi Covid-19.

Media penyampaian penyuluhan pun menjadi factor penting ketika hendak menyampaikan informasi ke anak-anak. Faktanya, Sebagian besar anak-anak sangat suka bermain. Mereka sangat cepat berada pada titik jenuh jika terpapar akan informasi yang disampaikan dengan cara formal atau kurang menarik bagi mereka. Melalui hal ini, media penyampaian merupakan hal penting untuk dipertimbangkan.

Salah satu metode yang paling sering digunakan yaitu metode ular tangga. Menurut penelitian Handayani, Monika dan Pipit (2019), penyuluhan kesehatan menggunakan metode ular tangga memberikan pengaruh terhadap pengetahuan remaja

\section{METODE PENELITIAN}

Penelitian ini dilakukan di desa Golong, kecamatan Narmada Lombok Barat di SDN 3 Golong. Sehingga populasi yang digunakan adalah siswa siswi di sekolah tersebut yang berjumlah sekitar 160 anak. Karena keterbatasan akses akibat covid-19, sampel yang digunakan berdasarkan estimasi yaitu 27 responden dengan usia 10-11 tahun dengan penentuan Non Probability Sampling. Responden diberikan kuesioner untuk pre-test sebelum permainan ular tangga dimulai dan dilanjutkan dengan pemberian post-test setelah permainan ular tangga selesai. Kuesioner tersebut terdiri dari 16 pertanyaan yang kemudian dianalisa menggunakan analisa statistik SPSS. Berikut merupakan alur penelitian : 


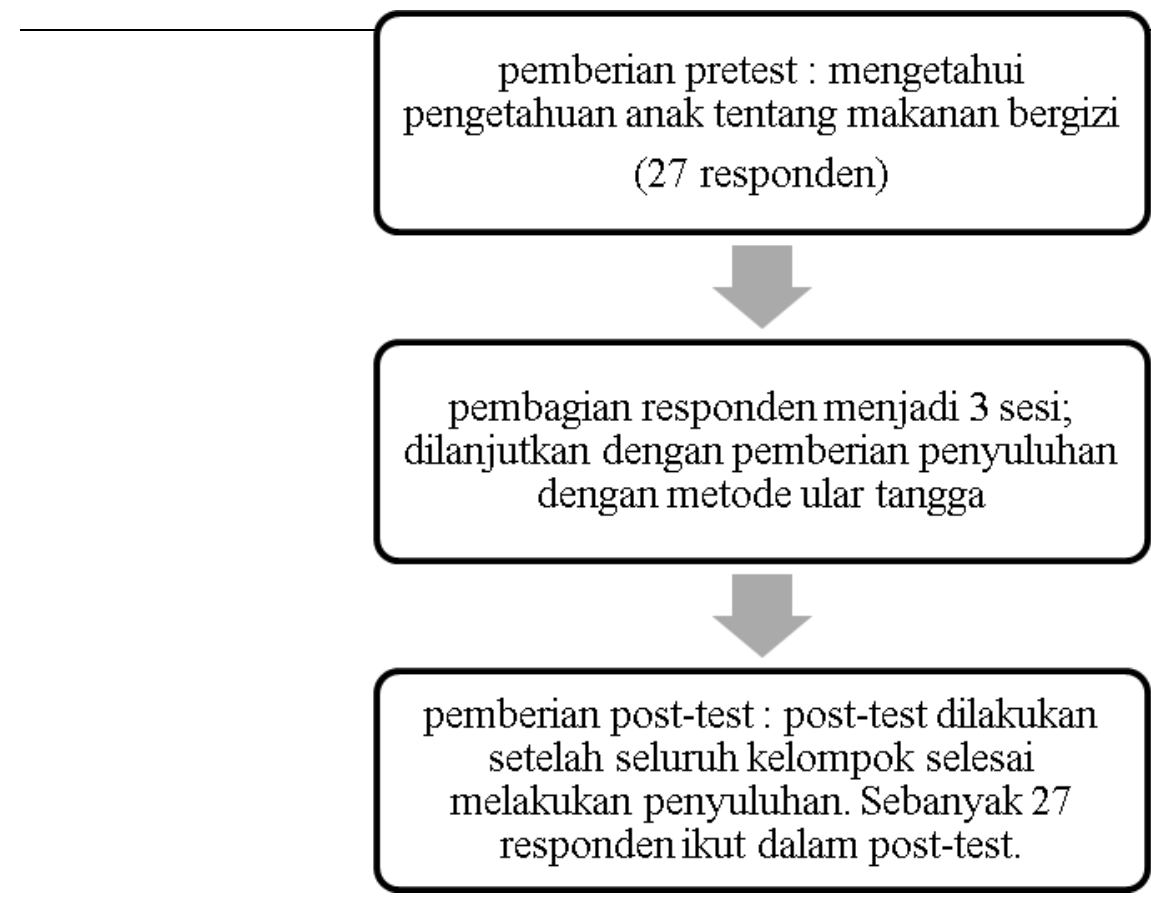

Gambar 1. Diagram alir proses penyuluhan dengan metode ular tangga

HASIL DAN PEMBAHASAN PENELITIAN

Tabel 1. Hasil analisis pengaruh penyuluhan makanan bergizi dengan metode ular tangga terhadap peningkatan pengetahuan anak desa Golong, Narmada tahun 2021

\begin{tabular}{lccccc}
\hline \multicolumn{1}{c}{ Variabel } & N & Minimum & Maximum & Mean & Std. Deviation \\
\hline Usia & 27 & 10 & 11 & 10.41 & .501 \\
Pre-test & 27 & 9 & 14 & 11.89 & 1.476 \\
Post-test & 27 & 12 & 16 & 14.52 & .849 \\
\hline
\end{tabular}

Hasil pre-test menunjukkan tingkat kemampuan anak-anak terhadap makanan bergizi. Berdasarkan table di atas, ditunjukkan bahwa nilai minimum pre-test yaitu 9 dan nilai maksimum yaitu 14. Nilai tersebut menunjukkan angka yang cukup dekat dengan nilai maksimal pada kuesioner yang diberikan. Tingkat pengetahuan dipengaruhi oleh banyak hal, seperti pada penelitian Yeni (2015) tingkat pengetahuan dipengaruhi oleh umur, tingkat Pendidikan, profesi dan juga sumber informasi. Selain itu, menurut Wardani, Sarwani dan Masfiah (2014) terdapat hubungan antara keaktifan dengan tingkat pengetahuan.

Setelah diberikan penyuluhan makanan bergizi menggunakan metode ular tangga, tingkat pemahaman anak meningkat meskipun tidak signifikan. Hasil post-test menunjukkan rata-rata 14.52 yang merupakan angka lebih besar dibandingkan rata-rata pre-test. Hal tersebut menunjukkan metode penyampaian informasi memberikan pengaruh terhadap peningkatan pengetahuan anak. Berdasarkan penelitian Zamzami (2014) penyampaian dengan metode ular tangga pada pendidikan kesehatan memberikan pengaruh terhadap sikap. Begitu juga dengan penelitian Handayani, Monika dan Pipit (2019) yang melakukan pendidikan kesehatan dengan metode ular tangga dapat meningkatkan 1,4 poin pengetahuan remaja terkait dampak perkawinan anak. Hasil tersebut didukung pula oleh penelitian Dewi, Kurnia dan Panjaitan (2017) yang menggunakan metode permainan ular tangga dalam meningkatkan hasil belajar siswa SD.

Metode pembelajaran merupakan hal yang penting untuk diperhatikan, karena metode pembelajaran dapat berguna sebagai alat motivasi ekstrinsik dengan meletakkan guru sebagai motivasinya. Anak-anak cenderung cepat merasakan kebosanan ketika metode pembelajaran tidak menarik, sehingga dalam pembelajaran penting untuk mengaplikasikan prinsip pembelajaran dengan atmosfir yang menyenangkan, menggembirakan 
penuh dorongan dan motivasi sehingga penerimaan materi dapat dilakukan dengan baik (Ilyas dan Syahid, 2018).

Berdasarkan hasil analisa terhadap variable usia, hal ini memberikan pengaruh terhadap peningkatan pemahaman anak meskipun tidak secara signifikan. Menurut Destria dan Palatro (2010) terdapat beberapa hal yang dapat mempengaruhi pengetahuan seseorang, salah satunya adalah umur. Oleh karena itu, usia juga dapat mempengaruhi tingkat pemahaman seseorang dalam menerima suatu informasi. Pada penelitian ini, usia dapat mempengaruhi tingkat pengetahuan anak dalam penyuluhan dengan metode ular tangga. Hal ini juga sesuai dengan penelitian Darmawati dan Wirata (2016) yang menyatakan bahwa pengetahuan anak dengan usia $>10$ tahun sangat baik, tetapi tidak memberikan hubungan yang signifikan antara umur dengan tingkat pengetahuan seseorang. Hal tersebut karena ketika usia seseorang telah cukup matang maka kemantapan dan kekuatan seseorang dalam berfikir semakin baik.

\section{KESIMPULAN}

Berdasarkan hasil dan pembahasan, maka dapat disimpulkan bahwa metode pembelajaran merupakan prinsip yang penting untuk dipertimbangkan dalam dunia Pendidikan karena hal tersebut berpengaruh terhadap penerimaan siswa terutama anak-anak. Metode ular tangga merupakan metode yang sering digunakan dalam penyampaian informasi terutama pada anak-anak karena merupakan metode yang tidak membosankan sehingga penyuluhan makanan bergizi dengan menggunakan metode ular tangga memberikan pengaruh terhadap peningkatan pengetahuan anak-anak di Desa Golong kecamatan Narmada.

\section{SARAN}

Berdasarkan hasil dan pembahasan pada penelitian ini, maka direkomendasi untuk melakukan pembelajaran dengan menggunakan metode ular tangga. Metode ini hendaklah didesain semenarik mungkin agar anakanak dapat menikmati proses pembelajaran. Selain itu, dapat dilakukan pula penelitian lanjutan terkait dengan metode pembelajaran lainnya yang dapat digunakan untuk meningkatkan pemahaman siswa/siswi.

\section{DAFTAR PUSTAKA}

Badan Pengawas Obat Dan Makanan (BPOM). Pedoman Pangan Jajanan Anak Sekolah Untuk Pencapaian Gizi Seimbang. Direktorat Standardisasi Produk Pangan, Deputi Bidang Pengawasan Keamanan Pangan dan Bahan Berbahaya, Badan Pengawas Obat dan Makanan RI. 2013. Hlm 11

Badan Perencanaan Pembangunan Nasional (BAPPENAS). Pembangunan Gizi Indonesia, Cetakan Pertama. Direktorat Kesehatan dan Gizi Masyarakat Kedeputian Pembangunan Manusia, Masyarakat dan Kebudayaan Kementerian PPN/Bappenas. 2019. Hlm xiv.

Dewi Tipani Liani, Kurnia Dadang, Panjaitan Regina Lichteria. Penggunaan Media Permainan Ular Tangga Pada Pembelajaran Pips Untuk Meningkatkan Hasil Belajar Siswa Pada Materi Pembagian Wilayah Waktu Di Indonesia. 2017;2 (1).

Dharmawati Ayu I.G.A.A, Wirata Nyoman I. Hubungan Tingkat Pendidikan, Umur, Dan Masa Kerja Dengan Tingkat Pengetahuan Kesehatan Gigi Dan Mulut Pada Guru Penjaskes Sd Di Kecamatan Tampak Siring Gianyar. 2016; 4 (1).

Handayani Sri, Monika Rika, Pipit Priska. Efektivitas Penkes Dengan Metode Ular Tangga Terhadap Pengetahuan Remaja Tentang Dampak Perkawinan Anak Di Smpn 2 Gunungkidul Yogyakarta. 2019;8(2):68-76

Ilyas. H. M, Syahid Abd., Pentingnya Metodologi Pembelajaran Bagi Guru. 2018;4(1)

Kementerian Kesehatan RI (KEMENKES). Pedoman Gizi Seimbang (Pedoman Teknis Bagi Petugas Dalam Memberikan Penyuluhan Gizi Seimbang), Katalog dalam terbitan Kementerian Kesehatan. 2014.Hlm 19.

Wardani Nur Indah, S.R. Sarwani Dwi, Masfiah Siti. Faktor-Faktor Yang Berhubungan Dengan Tingkat Pengetahuan Kader Kesehatan Tentang Thalassaemia Di Kecamatan Sumbang Kabupaten Banyumas. 2014;6(3): 194-206 
ISSN : 2656 - 2480 (Online)

ISSN : 2355 - 1364 (Print)

Yeni P.S.I, Faktor-Faktor Yang Berhubungan Dengan Pengetahuan Penggunaan Obat Generik Pada Masyarakat Di Wilayah Kerja Puskesmas Padang Panyang Kabupaten Nagan Raya Tahun 2015 [Skripsi]. Padang: Teuku Umar. 2015

Zamzami Muhammad. Pengaruh Pendidikan Kesehatan Dengan Metode Ular Tangga Tentang Pencegahan Penyakit Pes Terhadap Tingkat Pengetahuan Dan Sikap Siswa Sd Negeri 1 Selo Boyolali. 2014. 